\title{
O processo de revitalização e atividade turística no "Bairro do Recife" (Recife, Pernambuco, Brasil): interposições ao desenvolvimento humano no contexto das teorias das cidades sustentáveis e da Conservação Integrada
}

\section{Revitalization process and Tourism activity at the "Bairro do Recife" (Recife, Pernambuco, Brazil): interpositions to human development in the context of sustainable cities and Integrated Conservation theories}

\author{
Luis Henrique Souza (SOUZA, L. H.) ${ }^{*}$ e \\ Tomás Albuquerque Lapa (LAPA, T. A.) ${ }^{* *}$
}

\begin{abstract}
RESUMO - As cidades sustentáveis e a estratégia da Conservação Integrada põem em relevo a qualidade de vida subjacente aos projetos de intervenção urbana, os quais têm no Turismo uma motivação para suas concretizações. Tomando-se como referência os princípios das cidades sustentáveis e da conservação integrada, neste artigo se tem como objetivo analisar as dificuldades interpostas ao desenvolvimento humano do Bairro do Recife (Recife, Pernambuco, Brasil), decorrentes do processo de revitalização e turistificação deste centro histórico. A pesquisa bibliográfica, a observação sistemática e a análise qualitativa foram os principais recursos metodológicos desta pesquisa realizada no ano de 2013. Os resultados mostraram que as intervenções urbanas no Bairro do Recife reforçaram a exclusão social ao privilegiar as práticas da economia de mercado, ignorando-se o tecido social pré-existente à requalificação, não favorecendo, dessa forma, o desenvolvimento humano do local.
\end{abstract}

Palavras-chave: Turismo urbano; Sustentabilidade; Conservação integrada; Recife

ABSTRACT - The sustainable cities and the integrated conservation strategy highlights the quality life underlying the projects of urban intervention, which have in Tourism a motivation to turn them into reality. Taking as reference the principles of sustainable cities and integrated conservation strategy, this article aims to analyze the difficulties interposed to the human development of the "Bairro do Recife" (Recife, Pernambuco, Brazil), resulting from the revitalization process and Tourism activity in this historic centre. Bibliographic research, systematic observation, and qualitative analyses were the main methodological techniques of this research that was accomplished in 2013. The results showed that the urban interventions at the "Bairro do Recife" reinforced social exclusion by focusing on market economy practices, ignoring the social tissue that exists before the requalification, and thus do not promote the local human development.

Key words: Urban Tourism; Sustainability; Integrated Conservation; Recife.

\footnotetext{
* Formação: Graduação em Turismo pela Universidade Federal de Pernambuco (UFPE) e Mestrado em Turismo pela Universidade de Aveiro (Portugal). Atividade profissional: Professor do Departamento de Hotelaria e Turismo da UFPE. Endereço físico para correspondência: Av. Liberdade, 440, B1. 1, Ap. 1202. CEP: 50920-310 - Recife/PE - Brasil. Email: luis_rce@yahoo.com.br

*** Formação: Graduação em Arquitetura e Urbanismo pela Universidade Federal de Pernambuco (UFPE) e Doutorado em Geografia Humana pela Universidade Paris I, Pathéon Sorbonne. Atividade profissional: Professor do Departamento de Arquitetura e Urbanismo da UFPE. Endereço físico para correpondência: Rua Teles Júnior, 155, Ap. 1502. CEP: 52050-040 - Recife/PE - Brasil. Email: thlapa@ hotmail.com
} 


\section{INTRODUÇÃO}

Os debates sobre o meio ambiente, o desenvolvimento e a sustentabilidade imprimiram novas perspectivas à sociedade pós-moderna, promovendo esforços e tentativas de se desenhar um novo modelo econômico de produção, além de novas formas de organização social, todos direcionados à conservação do meio ambiente, ao uso sustentável dos recursos naturais e à melhoria da qualidade de vida. $\mathrm{O}$ desenvolvimento sustentável e a sustentabilidade são conceitos em permanente evolução. No contexto das cidades, por exemplo, refletem preocupações voltadas à mitigação das múltiplas fontes de poluição urbana, à promoção da cidadania, ao uso e configurações democráticas de ocupação do solo, às construções ecoeficientes, à busca pelas soluções em mobilidade etc., culminado, dessa forma, nos conceitos de cidades sustentáveis ou desenvolvimento urbano sustentável (CANEPA, 2007).

No mesmo raciocínio, são discutidos o presente e o futuro dos bens patrimoniais tangíveis e intangíveis das cidades em decorrência das intervenções urbanísticas voltadas para a modernização e inovação urbanas (DE LA MORA, 2012). A Conservação Integrada emerge nesta realidade como estratégia integradora perante as perspectivas dualistas entre a urbanização progressista e a manutenção e perpetuação da herança histórico-cultural comumente associada ao patrimônio (ZANCHETI; LAPA, 2012). No corpo teórico das cidades sustentáveis e da Conservação Integrada sobressaise a perspectiva da qualidade de vida que deve ser priorizada nos projetos de intervenção urbana (DE LA MORA, 2012). Neste sentido, constatam-se, desde os anos de 1990, sucessivos projetos de requalificação urbana e restauro de edifícios no histórico Bairro do Recife, localizado numa ilha na região central da cidade do Recife (Pernambuco, Brasil). Estes projetos introduziram novos dinamismos econômicos e culturais em sintonia com o padrão homogeneizador globalizado da economia de mercado. Porém, observou-se que o referido processo de revitalização não contribuiu para o desenvolvimento humano da população residente no bairro, reforçando um processo de exclusão e de perda da identidade da comunidade.

Diante deste cenário, quais seriam as principais dificuldades ou entraves subjacentes ao processo de revitalização do Bairro do Recife que se interpuseram ao desenvolvimento humano do local? Esta indagação conforma o problema de 
investigação deste artigo, no qual se tece seus principais resultados em torno dos princípios das cidades sustentáveis e da Conservação Integrada. Para esta abordagem, foi encetada uma discussão sobre os preceitos das cidades sustentáveis e das estratégias de intervenção urbana propostas pelo modelo da Conservação Integrada. Em seguida são diagnosticados os fatores restritivos ao desenvolvimento humano sustentável no Bairro do Recife.

\section{O DESENVOLVIMENTO URBANO SUSTENTÁVEL}

A difusão das ideias em torno da sustentabilidade recairia sobre as mais diversas atividades humanas. Tais conjecturas refletem um novo paradigma para as sociedades, onde crescimento econômico configura-se como condição necessária mas não suficiente, devendo ser priorizada uma forma de produção socialmente includente, ambientalmente sustentável e economicamente sustentada (SACHS, 2009).

No entanto, este novo paradigma do desenvolvimento acompanhou as próprias incertezas, imprecisões e questões do que vem a ser necessariamente a sustentabilidade: "Quem define o que é sustentabilidade? Como ela pode ser alcançada? A quem se destina a sua representação e significado?” A julgar pelos impactos produzidos pela ação antrópica ao meio ambiente e reconhecidos cientificamente, advoga-se que novos parâmetros de desenvolvimento devem ser estabelecidos sob pena de transgredir o princípio intergeracional da sustentabilidade.

Neste contexto, salta aos olhos uma incompreensão de como a sustentabilidade pode ser operacionalizada no tecido das atividades antrópicas. Neste ponto, Veiga (2010) questiona a urgência da sustentabilidade sobre candentes questões sociais e políticas como a fome, a miséria, as guerras, os sistemas políticos autoritários e as privações de liberdade da própria espécie humana. Se é dito que o desenvolvimento sustentável é um modelo em construção (CANEPA, 2007), ele parece reforçar sua essência antropocêntrica à medida que evolui.

Destaca Sachs (2009) que a dimensão prioritária da sustentabilidade é a social, porque esta é a própria finalidade do desenvolvimento. Do contrário, o colapso social poderá anteceder ao colapso ambiental. Não que haja um jogo de forças entre as 
dimensões ambientais e sociais da sustentabilidade, e sim uma sustentabilidade ampliada, que, segundo Canepa (2007), corresponde à sinergia entre o social, ambiental e o econômico, numa perspectiva intergeracional que pronuncia a ênfase antropocêntrica contida na ideia de sustentabilidade ampliada.

Tal assertiva pode ser constatada em Lovelock (2006 ${ }^{1}$ apud Veiga, 2010, p. 34) ao defender que "[...] a vida humana depende de uma Terra sadia [...]. Nossa preocupação com ela deve vir em primeiro lugar porque o bem-estar das massas crescentes de seres humanos exige um planeta sadio". Este planeta sadio possibilitará a perpetuação da existência da espécie humana sobre a terra, por onde se conclui que a dimensão ambiental da sustentabilidade não é apologética aos ecossistemas, à natureza ou à erosão da biodiversidade, e sim, reforça a ideia da abreviação do prazo da existência humana caso os aspectos sociais, econômicos e ambientais não forem tratados de forma balanceada.

Por outro lado, a abordagem antropocêntrica da sustentabilidade recebe um maior reforço ao se analisar o que Canepa (2007) denomina de sustentabilidade progressiva cujo foco situa-se no desenvolvimento com bases na diminuição da degradação ambiental concomitante à redução também da pobreza e das desigualdades. Veiga (2010) argumenta que a sustentabilidade progressiva se projeta numa ideia de coevolução entre o homem e a natureza, onde se mesclam fatores ecológicos, sociais, políticos, econômicos e culturais, sendo apenas aceitável o progresso conformado com aspectos relacionados à qualidade de vida. $\mathrm{O}$ autor também relaciona os principais fatores que caracterizam a qualidade de vida: saúde, educação, trabalho, mobilidade, lazer, segurança (integridade física relativa à criminalidade e desastres naturais), condições ambientais, segurança econômica e conexões sociais (VEIGA, 2010).

Outro aspecto importante na tônica da sustentabilidade progressiva reside no fato de que aspectos relacionados a oportunidades de acesso, liberdades cívicas e empregos decentes remetem a contextos de direitos coletivos, onde o crescimento econômico deve ser constituído por uma difusão de forças produtivas numa sociedade com o objetivo de proporcionar cidadania à toda a população (FRIEDMANN, $1996^{2}$

\footnotetext{
${ }^{1}$ LOVELOCK, J. A vingança de Gaia. Rio de Janeiro: Intrínseca, 2006.

${ }^{2}$ FRIEDMANN, J. Empowerment: uma política de desenvolvimento alternativo. Oeiras/Portugal: Celta, 1996.
} 
apud SACHS, 2009). Diante destas considerações, a atenção recai sobre o meio ambiente construído das cidades, espaço de aglomeração humana e das relações e tensões sociais, políticas e econômicas que claramente desafiam os pressupostos da sustentabilidade.

A vida nas cidades foi alterada significativamente a partir da Revolução Industrial, quando transcorreram migrações massivas no sentido campo-cidade (DAVIES, 1972). Desde então, o processo de urbanização e crescimento das cidades tornou-se inexorável à condição humana. Sejam as pequenas cidades, as quais Rybczynski (1996) explica que os ingleses batizam-nas por town (palavra do inglês arcaico tune, que significa "lugar fechado") ou as grandes cidades, ou cities - do francês arcaico cité - (RYBCVZYNSKI, 1996), desenvolvem diversos usos no âmbito de uma dimensão espacial. Tais usos, que viabilizam as funções cabíveis às cidades, são fontes de múltiplas externalidades. À proporção que crescem as cidades, ampliam-se, também, as exigências pelo uso do espaço e, neste aspecto, este autor destaca que problemas urbanos têm origem no uso e na organização da terra e não propriamente na escassez de terra para acomodar as múltiplas funções das cidades.

Blumenfeld (1972), em seu ensaio sobre a "metrópole moderna", aponta quatro componentes que necessitam de planejamento e organização espacial: comércio central, produção, moradia e áreas verdes. Destes, o autor destaca que, no uso da terra, a função habitacional das zonas residenciais apresenta problemas de grande envergadura como a favelização e a segregação racial e econômica. Para Blumenfeld (1972), o crescimento das cidades traz externalidades que impactam negativamente o meio ambiente, como o congestionamento no tráfego e sua consequente poluição atmosférica, e a poluição da água.

Por sua vez, Lynch (1972, p. 208) sugere que estas externalidades tornam as metrópoles locais desagradáveis para a habitabilidade: “a cidade é por demais quente, por demais ruidosa, por demais contundente; o ar é desagradável. [...] as sensações que experimentamos vão além dos nossos limites de conforto e mesmo de tolerância”. Nesta linha de raciocínio, Canepa (2007) salienta que a baixa qualidade de vida das cidades é responsável pelo desenvolvimento de diversos males sociais ou patologias urbanas a exemplo da solidão, da depressão, da violência e das epidemias. A autora completa o caráter inóspito das cidades pelo reconhecimento de novas terminologias que se 
agregaram ao cotidiano da habitabiliade urbana como a impermeabilização de solos, gerando impactos para absorção de elevados índices pluviométricos, os edificios doentes, a emissão de $\mathrm{CO} 2$ e seus impactos nocivos à camada de ozonio e as ilhas de calor que ampliam o desconforto térmico.

Os estudos dos autores anteriormente citados pontuam as cidades como um locus de pressões que perpassam as discussões e debates sobre o desenvolvimento sustentável, isto é, as cidades exercem um papel fulcral no cenário da sustentabilidade do planeta. Neste sentido, emergem os conceitos de cidades sustentáveis e do desenvolvimento urbano sustentável, os quais correspondem a um desdobramento das premissas e diretrizes da sustentabilidade para a realidade das cidades, conforme pode ser observado na definição de "cidades sustentáveis" apresentado pela Agência UNHABITAT (2005 ${ }^{3}$, apud CANEPA, 2007, p. 156):

[...] uma cidade onde as realizações e os avanços em desenvolvimento social, econômico e físico são feitos para durar. Uma cidade sustentável possui uma reserva durável de recursos naturais dos quais depende o desenvolvimento. [...]. Cidades sustentáveis são fundamentais para o desenvolvimento social e econômico.

Há, nesta definição, uma nítida preocupação com a perspectiva intergeracional, onde o desenvolvimento nas cidades conforma-se numa amplitude temporal, redundando com o próprio significado do termo "sustentável" ou, de modo específico, do termo "duràble" da língua francesa. O conceito, na forma em que se apresenta, suscita que a cidade sustentável é meio para o desenvolvimento socioeconômico, mas conjectura que o desenvolvimento socioeconômico é condição de partida para a existência de cidades sustentáveis.

Face à esta aparente dicotomia presente no conceito das cidades sustentáveis, cumpre assinalar que na Carta de Atenas ${ }^{4}$ foram definidas múltiplas funções para as cidades, as quais são aqui resumidas pela habitabilidade, mobilidade e cultivo do corpo e do espírito. Nesta ênfase, este documento coloca a qualidade de vida como prioritária nos projetos urbanísticos. Nas cidades sustentáveis deve prevalecer o desenvolvimento urbano sustentável que será alcançado pela:

\footnotetext{
${ }^{3}$ United Nations Human Settlements Programme (UN-Habitat, 1996).

${ }^{4}$ Documento resultante do IV Congresso Internacional de Arquitetura Moderna realizado em Atenas no ano de 1933 (LIRA; CABRAL, 2012).
} 
[...] (re) ordenação do espaço urbano a partir dos princípios básicos fundamentados no direito à sadia qualidade de vida, na administração democrática das cidades e na função social destas e da propriedade, juntamente com a adoção de mecanismos que incluam no mínimo a manutenção dos atuais estoques de recursos para as gerações futuras (CANEPA, 2007, p. 6).

De resto, novos desafios são assim postos ao urbanismo. A noção de cidades sustentáveis passa pela questão da qualidade de vida, resultando no advento de um urbanismo de base humanista. Canepa (2007) esclarece que este urbanismo tem a função de harmonizar o espaço de intervenção às realidades sociais pré-existentes, trazendo à ribalta, não apenas considerações técnicas, mas igualmente o reconhecimento das necessidades reais dos indivíduos e grupos sociais.

Entretanto, esta não parece ser uma tarefa fácil. Entre a idealização teórica proposta por Canepa (2007) e sua concretização prática, percebe-se um hiato derivado dos princípios do sistema econômico vigente que se manifesta por meros mecanismos de mercado, cuja lógica é excludente e beneficia aqueles que participam do sistema com recursos reais ou monetários. No domínio das cidades brasileiras prevalece a lógica da especulação imobiliária por parte da indústria da construção civil, que ocupa de forma desordenada os espaços através do excesso de construções verticalizadas ao extremo, provocando impactos negativos à paisagem, adensa as vias públicas pela impossibilidade destas receberem o excesso de tráfego, aumento no despejo de esgoto sanitário nos leitos pluviais, destrói as áreas verdes das cidades o que amplifica as ilhas de calor.

Canepa (2007, p. 45) adverte que a consecução das premissas das cidades sustentáveis exige "mudanças fundamentais não só no comportamento humano, mas principalmente na atuação do poder público no terreno da arquitetura e do planejamento urbano". Por este raciocínio, o urbanismo para cidades sustentáveis deve priorizar o direito à cidade através de um conjunto de ações que assegurem a qualidade de vida. Um componente essencial nesta mudança passa pelo sistemático diálogo com os cidadãos, considerado por Canepa (2007) um imperativo democrático como fórmula de subversão da hegemonia capitalista impositiva de valores, muitas vezes globais, a valores mais próximos às necessidades sociais locais.

Dentre as necessidades sociais locais, o urbanismo com vistas às cidades sustentáveis deve promover um amplo debate sobre a fundamentação histórico-cultural 
própria das cidades, materializada em seu patrimônio cultural, social e físico-natural. Neste ponto, os debates versam sobre a dialética entre os necessários progresso e modernização urbana e a preservação da memória das cidades. Na quebra de braço entre a renovação desenfreada e a proteção do meio ambiente urbano e sua história ecoam clamores contra a eliminação do patrimônio (no caso mais extremo) pelas forças hegemônicas econômicas. Um clamor que resgata a ética do uso dos espaços sob a premissa do direito a este uso pelos seus habitantes originais, legitimando formas de inclusão social e econômica a esta população, numa clara oposição aos frequentes processos de gentrificação promovidos pela espoliação urbana; o reconhecimento do lazer e da recreação como funções urbanísticas; o direito à manutenção da identidade e ao sentimento de pertencimento dos valores histórico-culturais das cidades. Sobre isto, afirma De La Mora (2012, p. 104):

Uma sociedade com história, que preserva e valoriza as suas produções culturais, a sua memória, o seu patrimônio tangível ou intangível é uma sociedade que poderá mais facilmente assumir sua identidade sociocultural própria e adotar atitudes coletivas, base do tecido social e de qualquer política de promoção de desenvolvimento.

Para Lapa (2012, p. 202), "quando o Estado falha [...], particularmente, no que se refere à conservação do patrimônio, o cidadão pode exercer, de forma individual ou organizada a competência de agente controlador da cidade, através de mecanismos jurídicos próprios”. Essa organização da sociedade representa um apelo para que os rumos da cidade e da conservação do patrimônio não sejam conduzidos por uma minoria elitista que não pensa o espaço urbano como um locus privilegiado de uma coletividade.

\section{CONFORMAÇÕES ENTRE AS CIDADES SUSTENTÁVEIS E A TEORIA DA CONSERVAÇÃO INTEGRADA}

A manutenção do patrimônio urbano histórico-cultural e a sua harmonização com novos projetos de intervenção urbanística compõem preocupações, discussões e debates que representam um novo paradigma no terreno da conservação urbana. A problematização converge para uma ruptura metodológica onde se aposta não mais em 
projetos estanques e isolados e de caráter monumentalista, e sim num direcionamento para uma perspectiva mais integrada e holística, a qual enfatiza o determinismo social no espaço e não apenas a ênfase econômica. Neste relevo, as práticas de conservação urbana conhecidas por Conservação Integrada (CI) têm conquistado notoriedade e merecido destaque nas pesquisas e práticas de planejamento e intervenção urbanos.

De acordo com Zancheti e Lapa (2012), a Conservação Integrada origina-se a partir das práticas reformistas da Itália dos anos de 1960 e 1970. O sucesso destas incursões perpassou a realidade deste país e seus princípios foram tomados como referência para a Europa a partir de sua sistematização na Declaração de Amsterdam em $1975^{5}$ (ZANCHETI; LAPA, 2012). Esta declaração, em linhas gerais, enumerou os princípios da CI, dentre os quais Zancheti e Lapa (2012, p. 20) destacam:

a) O patrimônio é uma riqueza social; sua manutenção, portanto, deve ser uma responsabilidade coletiva;

b) A recuperação de áreas urbanas degradadas deve ser realizada sem modificações substanciais da composição social dos residentes nas áreas reabilitadas;

c) Deve ser encorajada a participação de organizações privadas nas tarefas da conservação integrada;

d) Deve ser encorajada a construção de novas obras arquitetônicas de alta qualidade, pois serão o patrimônio de hoje para o futuro.

Dessa forma, a CI trata a conservação do patrimônio como indissociável a qualquer estratégia de conservação urbana, ao tempo que não corrobora com intervenções que visem à alteração radical no tecido social das áreas sob reabilitação e propõe uma estratégia de intervenção com viés participativo, incluindo o apoio da iniciativa privada. A CI se afasta também de intervenções urbanísticas que visem apenas a estética, desconsiderando as pessoas. Para De la Mora (2012), a CI contribuiu para que as políticas de preservação patrimonial evoluíssem do simples tombamento do monumento isolado para a busca da sua sustentabilidade. De resto, a CI assume a perspectiva da temporalidade e da historicidade para o patrimônio, onde o antigo assume novos valores que serão projetados para novas gerações e, o novo, surge dotado de um legado que será patrimonializado no futuro. Zancheti e Lapa (2012) esclarecem que esta é uma questão desafiadora, uma vez que os processos de intervenção urbana

\footnotetext{
${ }^{5}$ A declaração de Amsterdam foi o produto final do "Congresso sobre o Patrimônio Arquitetônico Europeu", realizado durante a reunião do Conselho da Europa no ano de 1975 (ZANCHETI; LAPA, 2012).
} 
devem incluir o novo numa relação de harmonia com o passado, do ponto de vista da cultura, do ambiente, das tradições construtivas e da forma.

Pela CI, o patrimônio de uma cidade assume uma perspectiva de um lugar dotado de vida, que sustenta atividades sociais (como habitação), econômicas (abrigando empresas de tecnologia ou do setor da economia criativa), culturais (museus, departamentos universitários, centros culturais, hotéis etc.), turísticas (hotéis, centros de interpretação do patrimônio) todas elas precípuas à coesão grupal, ao atendimento às necessidades sociais com sentido de promoção do bem-estar dos habitantes e visitantes. O dinamismo assim criado deve favorecer a sustentabilidade.

Diante destas reflexões, vê-se, portanto, uma conformação entre a Conservação Integrada e a concepção das cidades sustentáveis. As duas formulações defendem um urbanismo voltado para os anseios do tecido social local, cujas necessidades são legitimadas num processo democrático com participação ativa da população urbana. A CI é capaz de promover inclusão social e qualidade de vida uma vez que suas estratégias visam à harmonização e conciliação no dualismo antigo/novo; ao diálogo no âmbito da comunidade e dos múltiplos agentes do processo de desenvolvimento urbano e à legitimação do patrimônio das cidades como um valor que se soma ao contexto ambiental, social, cultural, político e econômico. Pela CI, os bens patrimoniais de uma cidade perpassam o tempo conforme a premissa intergeracional das cidades sustentáveis que defende, sobretudo, a adoção de mecanismos que assegurem manutenção dos atuais estoques de recursos naturais e culturais para as gerações futuras.

\section{METODOLOGIA}

No sentido de viabilizar os objetivos deste artigo, foram utilizadas as técnicas de pesquisa bibliográfica e estudo de caso, sendo desenvolvida uma abordagem qualitativa de natureza descritiva. As técnicas de coleta de dados se assentaram na entrevista estruturada e na observação de campo. Para a pesquisa bibliográfica, realizou-se uma discussão sobre os temas sustentabilidade, cidades sustentáveis e conservação integrada. O material pesquisado possibilitou confrontar as teorias das cidades sustentáveis e da conservação integrada à questões associadas ao turismo e ao desenvolvimento humano em centros históricos. 
Para diagnosticar as principais dificuldades e entraves no desenvolvimento humano pelo processo de revitalização, além da pesquisa bibliográfica, realizou-se um estudo de caso que teve como objeto o histórico Bairro do Recife. Nesta perspectiva, foram coletados dados sobre projetos inclusivos desenvolvidos no local, através de uma entrevista estruturada com o Diretor Executivo da Instituição Porto Digital, enquanto responsável pelo Parque Tecnológico instalado no Bairro do Recife. O Porto Digital é uma instituição do Governo do Estado de Pernambuco que atua desde o ano 2000 na governança do Arranjo Produtivo Local (APL) em Tecnologia, Informação e Comuniação (TIC), sendo responsável pela consecução de projetos estruturadores que atraem empresas de tecnologia para uso dos imóveis restaurados no Bairro do Recife (PORTO DIGITAL, 2013).

\section{ENTRAVES PARA O DESENVOLVIMENTO HUMANO PELO PROCESSO DE REVITALIZAÇÃO E TURISTIFICAÇÃO DO BAIRRO DO RECIFE ANTIGO}

A estratégia da CI é adequada para cidades latino-americanas, quase sempre dotadas de riquezas naturais, históricas e produtivas, porém, com registros de profundas concentrações de renda e dominação por parte de minorias elitistas. Nestas características se enquadra a cidade do Recife, localizada na região Nordeste do Brasil. Segundo o Instituto Brasileiro de Geografia e Estatística - IBGE (2010), o Recife encontra-se entre as dez cidades mais ricas do país, com o $9^{\circ}$ maior Produto Interno Bruto - PIB dentre as capitais brasileiras, porém, seu Índice de Gini ${ }^{6}$ é igual a 0,68, considerado alto por especialistas (IBGE, 2003). É também uma cidade que se aproxima dos 500 anos de existência e, portanto, dotada de um patrimônio histórico-cultural que requer estratégias urbanísticas que integrem a conservação deste patrimônio ao dinamismo da cidade.

Por sua vez, o Bairro do Recife, objeto do estudo de caso deste artigo, tem passado por diversas intervenções de revitalização de seu conjunto histórico, porém, a pesquisa documental identifica o local como detentor de um Índice de Desenvolvimento

\footnotetext{
${ }^{6}$ Índice de Gini mede a desigualdade de renda numa escala de 0-1, onde 1 significa alta concentração de renda.
} 
Humano - IDH igual a 0,7, considerado um IDH médio (CONDEPE-FIDEM, 2011). Ou seja, estas intervenções não têm contribuído para a melhoria do desenvolvimento humano do centro histórico, o que contrasta com as premissas das cidades sustentáveis e da Conservação Integrada. Nos parágrafos seguintes serão analisados alguns fatores que afastam o Bairro do Recife dos níveis sociais de desenvolvimento que poderiam ser articulados em função dos diversos projetos de intervenção urbanística com fins sobretudo turísticos e de lazer que incidem neste centro histórico.

O primeiro projeto de revitalização foi realizado no centro histórico do Bairro do Recife nos anos de 1990, que segundo Zancheti et al (1998), se tratou de um plano que visou introduzir novos usos para manter a continuidade do patrimônio construído no local. Dentre os novos usos estavam previstos os serviços modernos, os serviços de cultura e lazer, os serviços turísticos, o comércio varejista moderno e a habitação, de modo a dinamizar o espaço tanto no período diurno como noturno. Os autores também detalham que o Plano de Revitalização do Bairro do Recife (PRBR) dividiu o bairro em 3 setores: o Setor de Intervenção Controlada (Polos Alfândega, Bom Jesus e Arrecifes), que abriga as edificações de valor histórico-cultural; o Setor de Consolidação (Polo Capibaribe), onde se localizam as instituições públicas; e o Setor de Renovação Urbana (Polo Pilar).

De imediato, o projeto levou a uma valorização no preço de venda e dos aluguéis dos imóveis do bairro. Zancheti et al (1998) detalham que em 1993, o valor dos imóveis no Polo Bom Jesus era de R $\$ 124,00 / \mathrm{m}^{2}$, passando para $\mathrm{R} \$ 208,00 / \mathrm{m}^{2}$ em 1996. De acordo com os mesmos autores, houve registros de preços de aluguel em torno de R $\$$ $19,00 / \mathrm{m}^{2}$ a $\mathrm{R} \$ 20,00 / \mathrm{m}^{2}$ no Polo Bom Jesus, valores superiores aos praticados nos bairros nobres da cidade, como Boa Viagem, Espinheiro e Parnamirim. Enfatizam também os autores que a ocupação dos imóveis é predominantemente do andar térreo, ficando os andares superiores desocupados.

Verifica-se, portanto, que a valorização dos imóveis no bairro do Recife resultou num entrave para que o estoque imobiliário existente pudesse ser utilizado como função residencial. Carrión (2001) caracteriza um centro histórico como um assentamento humano vivo, no qual as políticas de CI devem estar alinhadas com as políticas oficiais de habitação, defendendo, assim, que os projetos de reabilitação de centros históricos criem oportunidades de habitação para os residentes do local. A imediata valorização 
dos imóveis no Bairro do Recife inviabilizou uma matriz urbana humanizada, com residentes fluindo pelo espaço e interagindo com o patrimônio através de atividades típicas do uso residencial do espaço. Importa destacar que as condições de habitação apresentam reflexos diretos no desenvolvimento humano, e o que se registra no Bairro do Recife é um estoque de prédios históricos desocupados em seus andares superiores e a existência da comunidade do Pilar que vive em condições inadequadas de habitabilidade.

A comunidade do Pilar, objeto de intervenção urbana do PRBR, apresenta os piores índices de inclusão social da cidade do Recife (NERY; CASTILHO, 2008). Está localizada na parte central do Bairro do Recife, representando a parte significativa dos seus habitantes que são flagelados pelos problemas sociais decorrentes das precárias condições sanitárias e de moradia. Dessa forma, se constituem como uma comunidade marginalizada na centralidade histórica do Bairro do Recife. Inicialmente, o PRBR previu a melhoria urbanística no espaço da comunidade, com restauro, inclusive da Igreja de Nossa Senhora do Pilar e de projetos voltados para o desenvolvimento comunitário, proporcionando geração de empregos, renda, de educação ambiental e patrimonial. Embora o PRBR seja dos anos de 1990, até 2008, conforme atestam Nery e Castilho (2008), nada havia sido feito no local.

Em 2008, a Prefeitura da cidade do Recife retomou o projeto e, nesta nova versão, estava prevista a construção de 470 unidades habitacionais, escolas, creche, posto de saúde da família, um centro comercial para venda de artesanato, locais de convívio como praças e, novamente, o restauro da Igreja do Pilar (PCR, 2013). Por observação realizada no local, registra-se que o projeto teve início apenas com a construção das moradias, entretanto, as obras estavam paralisadas, e os residentes na comunidade do Pilar permanecendo em seus barracos em precárias condições sanitárias e a margem dos projetos de revitalização e requalificação urbanas que ocorrem no Bairro do Recife.

Lacerda (2007) demonstra que a revitalização do bairro do Recife operou um processo no qual prevaleceram os interesses e usufrutos da elite recifense, dos empresários e do turismo e que não foi cumprida a forma de gestão compartilhada através da participação de todos os sujeitos patrimoniais, conforme prevê a Lei de Uso e 
Ocupação do Bairro do Recife ${ }^{7}$ e as estratégias da Conservação Integrada. Por fim, Lacerda (2007) reconhece que o processo de preservação dos valores patrimoniais no local não foi apropriado pela maioria da população e não contribuiu para o fortalecimento do sentido da cidadania.

A entrevista realizada com o diretor do Porto Digital comprovou esta assertiva. O entrevistado ressaltou que, embora a Organização fosse detentora de 50 mil metros quadrados de área revitalizada em prédios históricos, o Porto Digital não participava de nenhum fórum de discussão sobre planos e intervenções urbanísticos para o Bairro do Recife. Relatou também que, de fato, inexistia uma governança local que facilitasse o amplo debate na sociedade de modo que as ações urbanísticas e os novos usos dos edifícios históricos estejam pautados no bem comum da coletividade. Destacou, porém, que a Prefeitura realizava reuniões onde eram apresentadas as intervenções propostas para o Bairro, mas, que estas reuniões não se configuravam como um fórum participativo.

As cidades sustentáveis e a CI pressupõem a existência de mecanismos de gestão democrática de modo que os projetos de intervenção possam representar os verdadeiros anseios da população diretamente envolvida com o centro histórico, evitando que prevaleçam os interesses de minorias. Importa também destacar que, conforme princípio da CI, o patrimônio deve ser apropriado por um senso de responsabilidade coletiva, onde residentes e visitantes desenvolvam uma consciência sobre os valores do patrimônio. Esta sensibilidade pode ser ampliada pela educação patrimonial e, por sua vez, a realização sistemática de fóruns de discussão nos centros históricos propicia um formato legítimo para a sensibilização patrimonial, promovendo, dessa forma, o desenvolvimento humano pela educação.

Outro fator com reflexos diretos no desenvolvimento humano do Bairro do Recife se relacionava com a qualidade de vida urbana. Conforme Canepa (2007), no contexto das cidades sustentáveis, este é um fator que tem como base a qualidade ambiental, a redução da pobreza e das desigualdades, exclusão e vulnerabilidades sociais. Da mesma forma, Zanchetti e Lapa (2012) destacam que um dos princípios da CI ressalta que não se devem realizar modificações substanciais no tecido social dos residentes das áreas reabilitadas. Nesta visão, Nery e Castilho (2008, p. 20) defendem

\footnotetext{
${ }^{7}$ Disponível em: <http://www.recife.pe.gov.br/pr/leis/>.
} 
que "não adianta requalificar uma área de valor histórico desconsiderando a necessidade de incluir a população pobre residente". Entretanto, os processos de revitalização que se realizaram no Bairro do Recife favoreceram algumas classes sociais elitistas.

Os empregos gerados pelo Parque Tecnológico requerem alta especialização. Segundo o diretor do Porto Digital, alguns empregados apresentam titulações de mestre e doutorado, ou seja, estes cargos são inacessíveis à população carente da comunidade do Pilar. Além deste quesito, os prédios históricos revitalizados no bairro abrigam equipamentos de turismo, lazer e comércio, como shopping center, livrarias, galerias de arte, restaurantes, bares sofisticados e centros culturais mantidos por instituições financeiras, conferindo assim, novos usos ao espaço urbano restaurado. Estes equipamentos ofertam produtos e serviços segmentados para turistas e para residentes de outros bairros da cidade com melhor poder aquisitivo ou elitista, conformando um centro histórico excludente e concentrador de renda, inacessível aos habitantes da comunidade do Pilar. Conforme destacado por Nery e Castilho (2008) e Lacerda (2007), conflitam no Bairro do Recife o contraste social veiculado, por um lado, pelas estruturas que atendem à lógica do capital e que ocupam os prédios históricos do bairro e, por outro lado, os habitantes do bairro que foram privados das práticas sociais de convívio mais democráticas. Para esta comunidade resta a subsistência econômica da informalidade, do comércio de rua, da prostituição e da comercialização de produtos ilícitos (NERY; CASTILHO, 2008).

A observação de campo comprovou a afirmação dos autores. A planta de serviços instalada nos prédios revitalizados e a prioridade para os usos turísticos e de animação e lazer do espaço promovidos pelo poder público privilegiaram o acesso automobilístico ao bairro e, dessa forma, multiplicaram-se os guardadores de carro de rua. A incidência de festejos e eventos contribui para que os residentes do Pilar obtenham uma renda pelo comércio ambulante de lanches e bebidas. Entretanto, pela especificidade marginal dessas atividades, não é possível a mudança da condição econômica dessa população.

A realidade ora apresentada confere uma transgressão ao princípio das justas alocações econômicas das cidades sustentáveis, que se caracteriza por esforços para minimizar a desigualdade social por atividades econômicas mais justas à população. Através da prática de atividades econômicas marginais, os residentes do Bairro do 
Recife, por si próprios, não alteraram suas condições de habitabilidade e de oportunidades a melhores serviços de saúde e de educação, o que resulta em índices medianos de desenvolvimento humano para o bairro.

Cumpre porém destacar a existência de algumas iniciativas capitaneadas por organizações e empresas privadas que dinamizavam ações com vistas a dar usos sociais aos edifícios históricos do Bairro do Recife após processo de restauro. Toma-se o caso da organização Porto Digital, cujas ações de responsabilidade social têm contribuído para reaproximar o Bairro do Recife às premissas das cidades sustentáveis e da Conservação Integrada. Na cadeia produtiva da TIC, conforme anteriomente discutido, havia o predomínio de cargos que demandavam elevadas especializações profissionais. Porém, com vistas à inserção da comunidade local do Pilar no setor produtivo das TICs, algumas empresas pertencentes ao Parque Tecnológico instituíram programas que ofereciam treinamentos profissionalizantes aos jovens e aqueles que obtinham melhor desempenho eram admitidos por estas empresas. Após concluirem seus estudos, estes jovens também eram incentivados a ingressarem no ensino superior e a expectativa é que se somessem a esta mão de obra especializada.

Por outro lado, conforme depoimento do diretor do Porto Digital, houve no passado uma prioridade desta Organização no que diz respeito às incursões sociais na comunidade do Pilar, contemplando, por exemplo os projetos da Biblioteca do Pilar e o Projeto Informar, o qual incentivava o empreendedorismo entre os jovens. Este projetos duraram cerca de 6 anos e foram descontinuados, restringindo assim, as oportunidades de inserção profissional à população local, desfavorecendo a justa alocação econômica e mantendo a condição de precariedade dos trabalhos marginais da informalidade e das atividades ilícitas, dificultando, dessa forma, o desenvolvimento humano.

De resto, cumpre destacar que, em razão do Turismo e do favorecimento à especulação imobiliária, foram priorizados os processos de restauro e de revitalização dos prédios históricos e dos espaços públicos localizados em áreas privilegiadas como a Rua do Bom Jesus, Rua da Moeda, Marco Zero, Madre Deus, Alfândega e adjacências. A requalificação das áreas privilegiadas do Bairro do Recife contou com aportes financeiros oriundos do poder público (Prefeitura do Recife) e do Programa Monumenta/BID do Ministério da Cultura (NERY; CASTILHO, 2008). Em conformidade com os novos usos assentes na oferta de serviços de comércio, lazer e 
turismo, houve também significativo aporte de investimento privado nestes locais. Porém, no espaço da comunidade do Pilar, a Igreja de Nossa Senhora do Pilar resiste ao tempo e, embora seja tombada, nunca passou por nenhum processo de restauro e de requalificação de seu entorno, o que se conclui pelo esquecimento que passa a comunidade em todo o processo de requalificação do Bairro do Recife.

Zancheti e Lapa (2012), também sobre os princípios da CI, destacam que a conservação do patrimônio deve ser objeto de educação patrimonial, principalmente para os jovens. Como esperar que uma população seja patrimonialmente educada a partir da visão cotidiana da degradação de seu bem histórico? Como fortalecer a identidade da comunidade, promovendo a qualidade de vida através do patrimônio, quando se assiste ao esquecimento do seu bem patrimonial representativo? Além do problema do restauro do entorno da Igreja do Pilar, a observação da área do Porto da cidade do Recife revelou que seus antigos armazéns foram recentemente destruídos ou revitalizados para abrigarem os novos usos do lazer e turismo. Com investimentos de aproximadamente 100 milhões de reais, foi inaugurada em abril de 2014 a primeira etapa do Museu Cais do Sertão, que além de espaço museal, abrigou também um centro cultural dotado de auditório, salas multiuso, restaurante e cafés (PORTO DO RECIFE, 2013). Para viabilizar estas obras, foram demolidos os armazéns 9 e 10 do Porto, que embora deteriorados, cederam lugar aos valores do progresso e da visão hegemônica globalizada de intervenção urbana que se dissocia dos princípios das cidades sustentáveis e da CI.

Conforme pontuam Nery e Castilho (2008, p. 28), muitos dos atuais habitantes da comunidade do Pilar foram trabalhadores no próprio Porto do Recife e as demolições dos armazéns configuraram a impossibilidade de uma rememoração do cotidiano destes moradores, destituindo-os de seus próprios legados. Sobre esta problemática, Canepa (2007, p. 192), no contexto das cidades sustentáveis, elucida que: “é de particular relevância também, além da preservação do meio ambiente natural, a atenção com o meio ambiente cultural, pois tão importante quanto assegurar condições de vida respirável é a salvaguarda e a sobrevivência de legados históricos e artísticos”. Outros armazéns tiveram suas fachadas restauradas, entretanto, seu interior abrigava novos usos e, semelhantes aos usos dos novos edifícios e espaços que estavam em construção, estes novos usos não atendem à comunidade por falta de identidade com os produtos e 
serviços ou, principalmente, pela inacessibilidade aos mesmos por condições econômicas. Amplia-se assim, a exclusão e desfavorece o desenvolvimento humano do Bairro do Recife.

\section{CONSIDERAÇÕES FINAIS}

O conceito de cidades sustentáveis tem origem nos desdobramentos da teoria do desenvolvimento sustentável aplicada ao contexto urbanístico. Anterior à construção deste corpo teórico, a estratégia da Conservação Integrada recai sobre o dualismo entre os valores do progresso e os valores da rememoração, enfatizando que são os usos identitários do patrimônio que o projeta de modo sustentável para o futuro. Assim, observa-se que, embora o modelo das cidades sustentáveis e da estratégia da Conservação Integrada tenham origens em diferentes cronologias, nas reflexões teóricas abordadas neste artigo se reconhecem que estas duas estratégias de intervenção no espaço urbano apresentam interfaces e conformações sobre a qualidade de vida das cidades, enquanto redundam para a perspectiva intergeracional proposta pelo desenvolvimento sustentável. Demonstrou-se, também, que ambas as abordagens estão vinculadas à função de harmonizar o espaço de intervenção às realidades sociais préexistentes, defendendo a participação ativa da sociedade nos debates que envolvem os dualismos entre o apelo à modernidade e à manutenção dos espaços de rememoração.

A democratização dos centros históricos com base em sua apropriação pela diversidade de classes sociais são princípios basilares das cidades sustentáveis e da Conservação Integrada. Esta democratização prevê, sobremaneira, o envolvimento ativo da população residente nestes espaços no processo de revitalização dos centros históricos. A proposta de revitalização do Bairro do Recife obedece ao padrão homogeneizador globalizado com ênfase na economia de mercado, privilegiando atividades financeiras, comerciais e do uso do espaço para o lazer e turismo. Neste percurso, observou-se que na requalificação deste centro histórico se desconsiderou a existência da comunidade do Pilar que ocupa o espaço central do Bairro do Recife, reconduzindo-a a uma posição periférica de desenvolvimento. 
Os novos usos do centro histórico do Bairro do Recife têm caráter elitista e destinam-se ao consumo de produtos e serviços de classes privilegiadas, e exclui, dessa forma, o convívio democrático entre os habitantes locais e entre estes, os turistas e demais frequentadores do bairro. Constatou-se que as intervenções urbanas no local favoreceram o emprego informal, onde a população local sobrevive de ganhos do comércio ambulante e do serviço da guarda de carros que estacionam nas ruas do bairro; a destruição dos edifícios de rememoração da comunidade que contribui para a espoliação de sua identidade e do seu legado histórico; a faxina social decorrente da impossibilidade de ocupação dos imóveis restaurados em decorrência dos altos preços cobrados para a compra ou aluguel destes espaços. Estes fatores concretizam restrições ao desenvolvimento humano do Bairro do Recife e transgridem preceitos basilares das cidades sustentáveis e da Conservação Integrada. Por fim, verificou-se que estes fatores são potencializados ao se constatar a efemeridade dos projetos de responsabilidade social de muitas empresas e organizações instaladas no Bairro do Recife e a inexistência de uma participação democrática da população nos projetos de requalificação urbana do local.

\section{REFERÊNCIAS}

BLUMENFELD, H. A metrópole moderna. In: KNOFF, A. (Org.). Cidades: a urbanização da humanidade. Rio de Janeiro: Zahar Editores, 1972, p. 52-70.

CANEPA, C. Cidades sustentáveis: o município como lócus da sustentabilidade. São Paulo: RCS, 2007.

CARRIÓN, F. Medio siglo en camino al tercer milênio: lós centros históricos en América Latina. In: CARRIÓN, F. (Org.). Centros históricos de América Latina y el Caribe. Paris: UNESCO, 2001, p. 29-94.

CONDEPE/FIDEM - Agência Estadual de Planejamento e Pesquisa de Pernambuco. Desenvolvimento Humano na Região Metropolitana do Recife: Atlas metropolitano. Recife, 2011, ISBN: 978-85-60532-02-5. CD-ROM.

DAVIES, K. A urbanização da humanidade. In: KNOFF, A. (Org.). Cidades: a urbanização da humanidade. Rio de Janeiro: Zahar Editores, 1972, p. 13-35.

DE LA MORA, L. Modelos de planejamento local. In: LACERDA, N.; ZANCHETI, S. (Orgs). Gestão da conservação urbana. Olinda: Centro de Estudos Avançados da Conservação Urbana, 2012, p. 102-113. 
IBGE. Mapa de Pobreza e Desigualdade - Municípios Brasileiros 2003. Disponível em: <http://www.ibge.gov.br/estadosat/temas.php?sigla=pe\&tema=mapapobreza2003 >

Acesso em 12/05/2013.

IBGE. Produto Interno Bruto dos municípios 2010. Disponível em: <http://www.ibge.gov.br/home/estatistica/economia/pibmunicipios/2010/>. Acesso em: $12 / 05 / 2013$.

LACERDA, N. Intervenções no bairro do Recife e do seu entorno: indagações sobre sua legitimidade. Revista Sociedade e Estado, Brasília, v. 22, n. 3, p. 621-646. set./dez. 2007.

LAPA, T. Controle da Gestão da Conservação. In: LACERDA, N.; ZANCHETI, S. (Orgs). Gestão da conservação urbana. Olinda: Centro de Estudos Avançados da Conservação Urbana, 2012, p. 198-209.

LIRA, F.; CABRAL, R. Estrutura Internacional de Conservação. In: LACERDA, N.; ZANCHETI, S. (Orgs). Gestão da conservação urbana. Olinda: Centro de Estudos Avançados da Conservação Urbana, 2012, p. 56-69.

LYNCH, K. A cidade como meio ambiente. In: KNOFF, A. (Org.). Cidades: a urbanização da humanidade. Rio de Janeiro: Zahar Editores, 1972, p. 207-216.

NERY, N. S.; CASTILHO, C. J. M. de. A comunidade do Pilar e a revitalização do bairro do Recife: possibilidades de inclusão socioespacial dos moradores ou gentrificação. Humanae, v. 1, n. 2, p. 19-36, Dez. 2008.

PCR. Obras urbanísticas e inclusão social da comunidade do Pilar, 2013. Disponível em: <http://www2.recife.pe.gov.br/projetos-e-acoes/projetos/obras-urbanisticas-einclusao-social-da-comunidade-do-pilar/>. Acesso em: 10/07/2013.

PORTO DO RECIFE. O juazeiro dá as boas vindas, 2013. Disponível em: <http://www.portodorecife.pe.gov.br/saladeimprensa/2013-07-10-1.htm>. Acesso em: 12/07/2013.

PORTO DIGITAL. Inovação, empreendedorismo e capital humano. Disponível em: <http://www.portodigital.org/>. Acesso em: 12/07/2013.

RYBCZYNSKI, W. A vida nas cidades. São Paulo: Record, 1996.

SACHS, I. Caminhos para o desenvolvimento sustentável. Rio de Janeiro: Garamond, 2009.

VEIGA, J. Sustentabilidade: a legitimação de um novo valor. São Paulo, SENAC, 2010.

ZANCHETI, S.; MARINHO, G.; LACERDA, N. Revitalização do bairro do Recife: Plano, regulação e avaliação. Olinda: Recife: Ed. Universitária da UFPE, 1998. 
ZANCHETI, S.; LAPA, T. Conservação integrada: evolução conceitual. In: LACERDA, N.; ZANCHETI, S. (Orgs). Gestão da conservação urbana. Olinda: Centro de Estudos Avançados da Conservação Urbana, 2012, p. 18-31.

Recebido em: 26-06-2014.

Aprovado em: 26-07-2014. 